\title{
局麻手術後顕在化した両側内頸動脈閉塞例
}

\author{
三浦誠・八木 伸也 \\ 小形 哲也・篠原 尚吾
}

\section{Bilateral Internal Carotid Artery Occlusion with Cerebral Infarction after Operation; A Case Report}

\author{
Makoto Miura, Nobuya Yagi, \\ Tetsuya Ogata and Shogo Shinohara \\ (Kurashiki Central Hospital)
}

A 66-year-old man with bilateral internal carotid artery occlusion had a cerebral infarction after an endonasal operation under local anesthesia with so-called cocktail premedication. Because his preoperative physical examination was normal, routine cocktail premedication was given. The operation was performed without any trouble, but after operation, his blood pressure and level of consciousness were reduced and his tongue was deflected posteriorly. CT scan after operation showed cerebral infarction and brain atrophy. DSA (digital subtraction angiogram) proved bilateral old internal carotid artery occlusion. ${ }^{123}$ I-IMP SPECT (single photon emission computed tomography) showed severe decrease of cerebral blood flow.

In our clinic, 27 of 519 patients (5.2\%) operated on under local anesthesia with cocktail premedication had various side effects, but all were transient. This patient had bilateral internal carotid artery occlusion before operation and apparent cerebral infarction due to drop of blood pressure- a rare occurrence. It was impossible to predict bilateral internal carotid artery occlusion at the time of preoperative routine physical examination. To find bilateral internal carotid artery occlusion without symptoms is an important problem to be solved.

Key words: cerebral infarction, bilateral internal carotid artery occlusion, local anesthesia, side effect

\section{はじめに}

いわゆるカクテル麻酔は局麻下手術に際して, 疼痛の軽減, 出血量の減少が期待できるため,

鼻・副鼻腔手術, 中耳手術には好んで用いられ

る. 一方カクテル麻酔には副作用として血圧低

下，ショックなどが生じることがある。
最近我々は, カクテル麻酔を用いた鼻内手術 に执いて術中舌根沈下，術後血圧低下，意識障 害, 覚醒後脳梗塞が発症し, 諸検査にて術前よ りの両側内頸動脈閉塞が明らかになった一症例 を経験したので，当科に拈けるカクテル麻酔の 統計的考察を含めて報告する. 


\section{症例}

症例：66歳, 男性.

体重 $62 \mathrm{~kg}$, 身長 $161 \mathrm{~cm}$.

\section{主訴：鼻閉}

既往歷: 30 年前に両副鼻腔根治術. その他特 記すべきことなし。

家族歴：特記すべきことなし。

現病歴： 1 年半前より鼻閉・鼾が増強し, 夜 間無呼吸発作を生じることもあった。

平成 2 年 8 月 9 日初診時の所見として, 両鼻 腔内に鼻茸が充満し, 鼻X-P 上副鼻腔炎術後再 発の所見が認められた。高齢ではあるが本人の
希望もあり，鼻閉の改善のために両鼻内篩骨洞 開放術を予定した。

術前検査として行った全検血, 生化学, 出血 凝固系検査，胸部 X-P，ECG，尿検査では異 常は認められなかった。

平成 2 年 9 月 26 日手術を施行した。 カクテル 麻酔前投薬として，術前90分前にペチロルファ ン ${ }^{\circledR} 50 \mathrm{mg}$ ，コントミン ${ }^{\circledR} 10 \mathrm{mg}$ ，アタラックス $\mathrm{P}^{\circledR} 25 \mathrm{mg}$ 筋注, 術前30分前にペチロルファン ${ }^{\circledR}$ $50 \mathrm{mg}$, コントミン ${ }^{\circledR} 10 \mathrm{mg}$ ，アタラックス $\mathrm{P}^{\circledR}$ $25 \mathrm{mg}$ ，アトロピン ${ }^{\circledR} 0.5 \mathrm{mg}$, レプチラーゼ $\mathrm{S}^{\circledR}$ $1 \mathrm{~A}$ 筋注を行った。この前投薬は，当科に於け

表 1 術前 前投薬

\begin{tabular}{|c|c|c|c|}
\hline ペチロルファン ${ }^{\circledR}$ & $50 \mathrm{mg}$ & \multirow{3}{*}{ 術前 90 分前 } & \multirow{3}{*}{ 筋注 } \\
\hline コントミン ${ }^{\circledR}$ & $10 \mathrm{mg}$ & & \\
\hline アタラックス $\mathrm{P}^{\circledR}$ & $25 \mathrm{mg}$ & & \\
\hline ペチロルファン ${ }^{\circledR}$ & $50 \mathrm{mg}$ & \multirow{5}{*}{ 術前 30 分前 } & \multirow{5}{*}{ 筋注 } \\
\hline コントミン® & $10 \mathrm{mg}$ & & \\
\hline アタラックス $\mathrm{P}^{\circledR}$ & $25 \mathrm{mg}$ & & \\
\hline アトロピン ${ }^{\circledR}$ & $0.5 \mathrm{mg}$ & & \\
\hline レプチラーゼ $\mathrm{S}^{\circledR}$ & $1 \mathrm{~A}$ & & \\
\hline
\end{tabular}

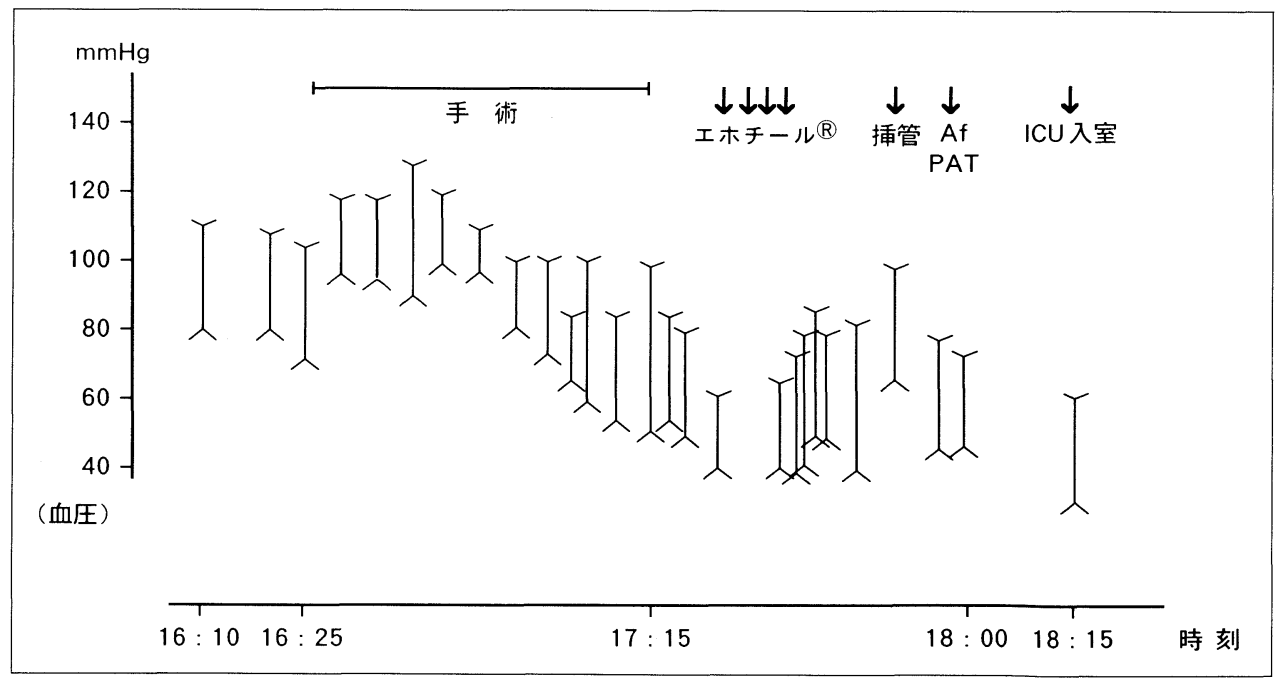

図 1 術中より ICU 入室までの経過 
るカクテル麻酔の標準処方であり，体重・年㱓 ・全身状態によって用量を決定する. 本症例の 場合は全身状態良好で術前検査は正常であり， 標準用量を使用した(表 1 ).

図 1 に経過を示す，手術室入室時血圧 110 / 80 ，前投薬による鎮静が著明で舌根沈下による 鼾が見られた。両鼻内篩骨洞開放術を午後 4 時 25分上り開始し 5 時15分に終了した．術中血圧 は安定していたが，手術終了直後に血圧低下が 起こり60台に低下した。点滴速度を上げェホ チール®静注を行らが，血圧の回復が悪いため 麻酔科医に診察を依頼したところ，舌根沈下が 強くなってきたため，捜管により呼吸管理する ことになった．挿管前血圧は100/60であった が挿管後血圧は低下し，発作性心房性頻拍 (PAT)，心房細動 (Af) の不整脈が出現した．抗 不整脈剤の投与により不整脈は消失し，血圧も 回復したが前投薬による鎮静が取れるまで ICU 管理を行った。翌日午前中には覚醒した ため抜管し，耳鼻科病棟に帰室した。しかし帰 室後も意識レベルが低く，翌 9 月28日には見当 識障害が明らかになったので頭部 CT を撮影し たところ，脳梗塞が明らかになった。以後は神 経内科医による加療を行った。9月30日には誤 嬿性肺炎を併発し再び ICU 入室となった。挿 管による呼吸管理を行い，10月 8 日には気管切 開を行った。呼吸不全は徐々に回復し，10月11 日に内科病棟に転棟した。その後はリハビリ テーションを続け, 平成 3 年 4 月 21 日現在, 右 上下肢の軽度運動障害が残存するのみで意識障 害, 燕下障害, 構音障害はなく, 外来通院で日 常生活は可能な状態になっている。術前よりあ る sleep apneaは末梢性パターンを示し，上気 道閉塞によるものであるため，気切孔閉鎖は行 わずに経過観察中である。

本症例の頭部 CT 像を示す (図 2 ). 左中大脳 動脈, 後大脳動脈の境界領域の脳梗塞を認め, 左中大脳動脈領域全体の血流低下，強い脳萎縮 (特に前頭葉), 陳旧性小梗塞が散見される点が 指摘された。
DSA (digital subtraction angiogram) 所見で は両側内頸動脈が起始部で完全閉塞しており, 脳血流は椎骨動脈系を介して行われていること が判明した(図 3 ).

${ }^{123}$ I-IMP SPECT (single photon emission computed tomography) 動脈採血法による $\mathrm{r}$ CBF (regional cerebral blood flow) color map にて脳血流量の全般的低下が著明で，特に左中 大脳動脈領域の低下が認められた（図 4).

心エコーで心房内血栓等は見られず，不整脈

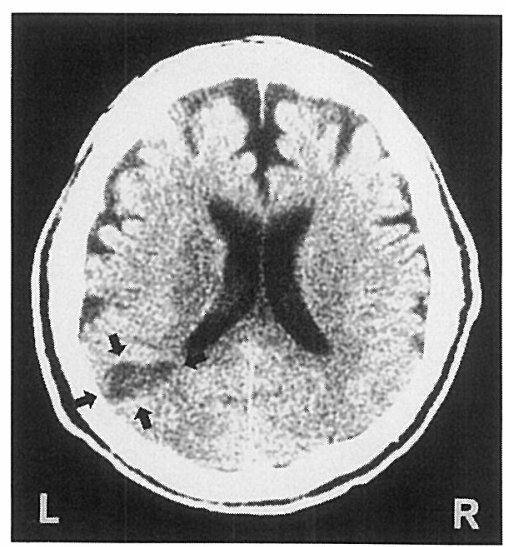

図 2 CT 像

左中大脳動脈, 後大脳動脈境界領域の梗塞像 (矢印で囲んだ部分).

強い脳萎縮 (特に前頭葉), 陳旧性小梗塞像を 認める。

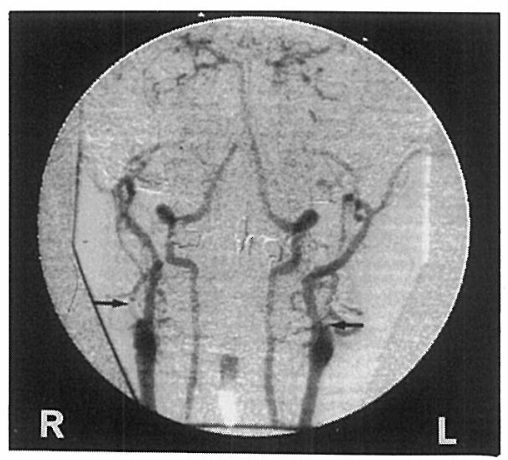

図 3 DSA (digital subtraction angiogram)

両側内頸動脈が起始部で完全閉塞している(矢印). 
による脳塞栓は否定的であった。術前より両側 内頸動脈閉塞による慢性脳血流不全があり，脳 萎縮，不顕性小梗塞が見られていたところに， 術直後の血圧低下を契機に，脳梗塞が顕在化し たと考觉られた。

\section{カクテル麻酔の副作用の結果}

当科に抒いて過去 2 年間にカクテル前投薬に 上る局麻下，鼻・副鼻腔手術，中耳手術は男性 298名，女性221名の計519名であった。平均年 齢は 42.7 歳, 平均体重は $59.0 \mathrm{~kg}$ であった。 519 名中, 術中・術後に処置を要した症例は,
表 2 処置を要した症例

\begin{tabular}{|c|c|}
\hline 血圧低下（80 以下） & 18名 (3.5\%) \\
\hline 悪心・顔色不良 & 7 名 (1.3\%) \\
\hline チアノーゼ・四肢冷感 & 2名 $(0.4 \%)$ \\
\hline 血圧上昇 & 7 名 (1.3\%) \\
\hline 不安 ·体動 - 疼痛 & 6 名 (1.2\%) \\
\hline \multirow[t]{3}{*}{ 不整脈（VPC） } & 1 名 $(0.2 \%)$ \\
\hline & $\begin{array}{l}27 \text { 名 }{ }^{*}(5.2 \%) \\
\text { 世重模例を考虑した实数 }\end{array}$ \\
\hline & 519 名 (100\%) \\
\hline
\end{tabular}

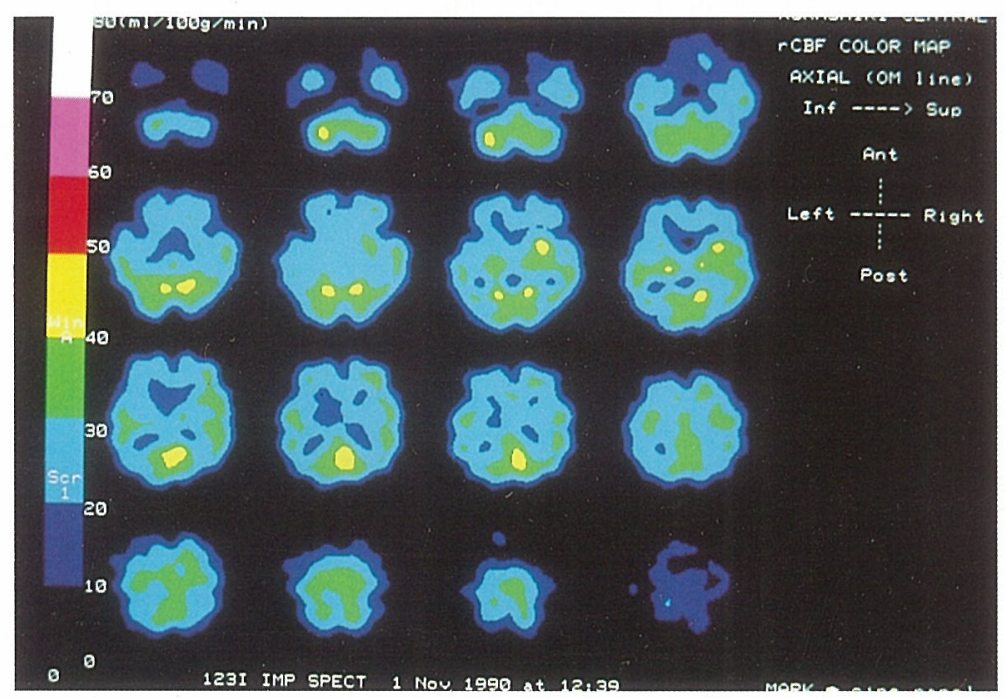

図 4 123I-IMP SPECT

全般的な脳血流低下が著明で特に左中大脳領域に著しい。

表 3 薬物治療

\begin{tabular}{|c|c|c|c|c|}
\hline エホチール & 12名 & （平均年齡 & 44.6 歳 / 平均体重 & $56.0 \mathrm{~kg})$ \\
\hline アダラートR & 7 名 & （平均年齢 & 59.0 歳 / 平均体重 & $58.1 \mathrm{~kg})$ \\
\hline プリンペラン ${ }^{\mathbb{R}}$ & 3名 & （平均年齢 & 39.0 歳 / 平均体重 & $65.7 \mathrm{~kg})$ \\
\hline セルシン ${ }^{R}$ & 6 名 & （平均年齢 & 52.8 歳 / 平均体重 & $59.9 \mathrm{~kg})$ \\
\hline ソルコーテフ ${ }^{\circledR}$ & 4名 & （平均年齢 & 52.8 歳 / 平均体重 & $60.5 \mathrm{~kg})$ \\
\hline $\begin{array}{l}\text { レペタン } \\
\text { ソセゴン }\end{array}$ & 3 名 & （平均年龄 & 53.7 歳 / 平均体重 & $58.3 \mathrm{~kg})$ \\
\hline キシロカイン ${ }^{\mathbb{R}}$ & 1名 & 年齢 & 60 歳 / & $63.0 \mathrm{~kg})$ \\
\hline 全症例 & 9名 & （平均年齢 & 42.7 歳 / 平均体重 & $59.0 \mathrm{~kg})$ \\
\hline
\end{tabular}


血圧低下 $(80$ 以下)が18名 $(3.5 \%)$, 悪心・顔色 不良が 7 名 $(1.3 \%)$, チアノーゼ・四肢冷感が 2 名 $(0.4 \%)$, 血圧上昇が 7 名 (1.3\%), 不安・ 体動・疼痛が 6 名 $(1.2 \%)$, 不整脈 (VPC) を生 じた症例が 1 名 $(0.2 \%)$ であり, 重複例もある ため処置を要した症例は27名で全体の5.2\%に 当たった(表 2 ).

処置に際して使用した薬物には, エホチー 几® 12 名, アダラート ${ }^{\circledR} 7$ 名, プリンペラン ${ }^{\circledR}$ 3 名, セルシン 6 名, ソルコーテフ ${ }^{\circledR} 4$ 名, レペタン®・ソセゴン® 3 名, キシロカイン ${ }^{\circledR} 1$ 名で, 全症例と比較して平均体重には大差がな いが，平均年齢では薬物使用例が高くなる傾向 があり, 高齢者に対しては十分な注意が必要で あると思われた(表 3 ).

\section{考 察}

今回の我々の統計によると, カクテル麻酔で 起こった副作用は高齢者に発生しやすい傾向が あるものの, 全例一過性であった。本症例のよ らに脳梗塞を発生したことは極めて稀らしいと 思われる。

両側内頸動脈閉塞は閉塞性血管障害患者の 5 〜20\%をしめるとされている1) 3). 症状として は重篤な神経脱落症状を示し死に至るものから 無症状のものまで様々であるが4) 8), 無症状も しくは一過性脳虚血発作 (TIA) などの比較的 軽症例は20～ $40 \%$ といわれている1)3). また当 症例のように前頭葉の萎縮が強く見られる点も 特徵とされる ${ }^{3)}$. 高血圧, 動脈硬化などを基礎 にもつ高齢者に多いが, 不顕性外傷による若年 者症例の報告もある5). DSA の進歩により9) 今 後軽症例の発見率が増大寸ると考えられている 疾患である. 本症例は TIA 発作の既往もなく, 高血圧の治療歴もない両側内頸動脈閉塞症例で 上記の $20 \sim 40 \%$ に含まれる例であり, 後に施行 したDSAにてはじめて確認されている.

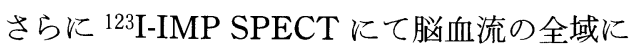
わたる著明な低下が認められ，実際は high risk 例であったと考光られるが, 我々が通常行 っている術前検査では予知不可能であった。今
後検討すべき問題点であると思われる.

また本症例は術前より斯が強く, 時に sleep apnea が見られていた点にも注目すべきである 5. 術後の検査にて上気道閉塞パターンである ことがわかったが，術中前投薬による鎮静が上 気道閉塞をきたし，低酸素血症が生じて脳血流 不全と共に脳梗塞の発症に関与した可能性も考 えられる.钼の強い症例に対しても十分な注意 が必要であろう。術中, パルスオキシメーター による経皮的酸素飽和濃度の測定は, 簡便で有 用な対応策となるのではないかと考光ている。

\section{まとめ}

1) カクテル前投薬による局麻下鼻内手術に 際して, 舌根沈下・血圧低下・意識障害が出現 し, 覚醒後脳梗塞が明らかになった両側内頸動 脈閉塞症例を報告した。

2）過去 2 年間に拈いてカクテル前投薬の副 作用を示した症例は519名中27名(5.2\%)で，い ずれも一過性のものであった。

3 ）本症例は両側内頸動脈閉塞が基礎にあっ た high risk 症例であるが, 通常の術前検查で は予知困難であり, 今後の検討課題であると考 兄れる。

本論文の要旨は第 16 回日本耳鼻咽喉科学会中国四 国地方部会連合学会で発表した。

\section{参考文献}

1) Waltimo $O$ and Fogelholm $R$ : Bilateral internal carotid artery thrombosis. Acta Neurol Scand $51: 240 \sim 244,1975$.

2) Yates PO and Hutchinsan EC : Cerebral infarction, the role of stenosis of the extracranial cerebral arteries. Med Res Counc Spec Rep Ser (LONDON) $300: 1 \sim 95,1961$.

3）榊 寿右, 横山和弘, 森本哲也, 他: 両側内頸 動脈閉塞症の臨床的検討. 脳神経 $33: 393 \sim 398$, 1981.

4) Berger R, McCaffrey JF and Baver RB : Bilateral internal carotid artery occlusion. Arch Surg $115: 840 \sim 843,1980$.

5) Sadun AA, Sebag J and Bienfang DC : Com- 
plete bilateral internal carotid artery occlusion in a young man. J Clin Neuro Opthalmol $3: 63$ $\sim 66,1983$.

6）倉田浩光, 富士原正保, 玉木紀彦, 他 : 両側内 頸動脈閉塞に合併した椎骨脳底動脈瘤の一例. 脳卒中 $11: 255 \sim 258,1989$.

7) Markwalder TM, Starrett RW and Mumenthaler M : Spontaneous bilateral recanalization in bilateral carotid artery occlusion. Stroke $11: 1 ; 95 \sim 98,1986$.

8) Howard GF, Ho SU, Kim KS, et al : Bilateral carotid artery occlusion resulting from giant cell arteritis. Ann Neurol 15 : 204 207, 1984.

9) Awad I, Little JR, Modic MT, et al : Intravenous digital subtraction angiography; an index of collateral cerebral blood fow in internal carotid artery occlusion. Stroke 13 : $4 ; 469 \sim 472,1982$.

\footnotetext{
/原稿受付 : 平成 3 年 4 月 22 日

原稿採択: 平成 3 年 5 月 29 日

別刷請求先 : 三浦 誠

T524 滋賀県守山市守山町120-6

滋賀県立小児保健医療センター耳鼻咽喉科)
} 